\title{
ADDENDUM
}

DOI: $10.1038 / s 41467-018-03076-4$

\section{Addendum: Shear-induced Notch-Cx37-p27 axis arrests endothelial cell cycle to enable arterial specification}

\author{
Jennifer S. Fang 1,2,3,4, Brian G. Coon (10) 1,2,3, Noelle Gillis ${ }^{1,2,3,4}$, Zehua Chen ${ }^{5}$, Jingyao Qiu1,2,3,4,6, \\ Thomas W. Chittenden ${ }^{5,7,8}$, Janis M. Burt ${ }^{9}$, Martin A. Schwartz (1) 1,2,3,10,11 \& Karen K. Hirschi (1) 1,2,3,4,6,11
}

Addendum to: Nature Communications https://doi.org/10.1038/s41467-017-01742-7, published online 15 December 2017

Publication of this Article was delayed due to technical issues during the production process. The Article should have been copublished with a related paper by Iruela-Arispe and colleagues ${ }^{1}$.

Published online: 14 February 2018

\section{References}

1. Mack, J. J. et al. NOTCH1 is a mechanosensor in adult arteries. Nat. Commun. 8, 1620 (2017).

\begin{abstract}
(c) (i) Open Access This article is licensed under a Creative Commons Attribution 4.0 International License, which permits use, sharing, adaptation, distribution and reproduction in any medium or format, as long as you give appropriate credit to the original author(s) and the source, provide a link to the Creative Commons license, and indicate if changes were made. The images or other third party material in this article are included in the article's Creative Commons license, unless indicated otherwise in a credit line to the material. If material is not included in the article's Creative Commons license and your intended use is not permitted by statutory regulation or exceeds the permitted use, you will need to obtain permission directly from the copyright holder. To view a copy of this license, visit http://creativecommons.org/licenses/by/4.0/.
\end{abstract}

(c) The Author(s) 2018

\footnotetext{
${ }^{1}$ Department of Medicine, Yale University School of Medicine, 333 Cedar Street, New Haven, CT 06520, USA. ${ }^{2}$ Yale Cardiovascular Research Center, Yale University School of Medicine, 333 Cedar Street, New Haven, CT 06520, USA. ${ }^{3}$ Vascular Biology and Therapeutics Program, Yale University School of Medicine, 333 Cedar Street, New Haven, CT 06520, USA. ${ }^{4}$ Yale Stem Cell Center, Yale University School of Medicine, 333 Cedar Street, New Haven, CT 06520, USA. ${ }^{5}$ Computational Statistics and Bioinformatics Group, Advanced Artificial Intelligence Research Laboratory, WuXi NextCODE 55 Cambridge Parkway, 8th Floor, Cambridge, MA 02142, USA. ${ }^{6}$ Department of Genetics, Yale University School of Medicine, 333 Cedar Street, New Haven, CT 06520, USA. ${ }^{7}$ Division of Genetics and Genomics, Boston Children's Hospital, Harvard Medical School, A-111, 25 Shattuck Street, Boston, MA 02115, USA. ${ }^{8}$ Department of Biological Engineering, Massachusetts Institute of Technology, 21 Ames Street \#56-651, Cambridge, MA 02142, USA. ${ }^{9}$ Department of Physiology, College of Medicine, The University of Arizona, 1501 N. Campbell Road, Tucson, AZ 85724, USA. ${ }^{10}$ Department of Cell Biology, Yale University School of Medicine, 333 Cedar Street, New Haven, CT 06520, USA. ${ }^{11}$ Department of Biomedical Engineering, Yale University School of Medicine, 333 Cedar Street, New Haven, CT 06520, USA. Correspondence and requests for materials should be addressed to K.K.H. (email: karen.hirschi@yale.edu)
} 